\title{
SEMIOLOGICAL VALUE OF PAINFUL SENSITIVITY OF THE TESTIS IN SPINAL CORD INJURIES
}

\author{
By E. Berard, B. Perrin, A. Leriche, P. Minaire, R. Girard and J. Bourret \\ Hôpital Henry Gabrielle, Route de Vourles, F6923o Saint-Genis-Laval, France
}

Abstract. About 85 cases of spinal cord male injured patients; the authors bring their experience of the painful sensitivity of the testis by squeezing the gland. This sign has a semiological value about the topography and the level of complete and incomplete cord syndromes. It is of no value for the testicular fertility. The rehabilitation of neurological bladders must take this sign into account so as to appreciate the type of micturition.

Key words: Testicle; sensitivity; spinal cord injuries.

THERE are various opinions about testicular innervation. For I year, we have been systematically seeking for the testicular sensitivity in 85 male patients with spinal cord injuries, so as to find out its semiological value.

We studied to see if there was a link between that sensitivity and the vesical reactions of the patients, and also with the testicular fertility.

\section{Material}

In 85 male patients with spinal cord injuries ( 60 of them were younger than 30 ) we systematically tried to find the painful sensitivity by pressing both testicles.

Of course, in normal subjects, squeezing of this gland produces the same: intense pain as in one of the most internal organs.

We haven't taken into account either the projected feelings in the abdomen or any other vague feelings, but only mentioned the painful sensitivity of the gland itself.

Our study concerns 57 complete transverse spinal cord injuries, and 28 incomplete ones of any type.

Within a period from 7 days to 5 years after the onset of the paraplegia, we performed 27 testicular biopsies or spermograms, as the patients asked for it.

In 2 I cases we drew a parallel between the type of bladder and the painful sensitivity or insensitivity of the testis, considering the neurological level.

Let us mention here that in France we speak of the first level affected by the cord injury and not the last sound one as in England.

\section{Clinical Findings}

The Painful Sensitivity of the Testis and the Neurological Syndrome

(a) In complete transverse syndromes (Table I):

Above Tio, there is no painful sensitivity of the testis.

Below TII, sensitivity is present in all cases.

At Tio, it is never present.

At TII, it is not constant. 


\section{TABLE I}

Painful sensitivity of the testis in complete syndromes

\begin{tabular}{lccr}
\hline Complete & No. of cases & $\begin{array}{c}\text { Testicular } \\
\text { sensibility }\end{array}$ & $\%$ \\
\hline $\begin{array}{l}\text { Above Tio } \\
\text { Paraplegia at Tio }\end{array}$ & 32 & 0 & 0 \\
$\begin{array}{l}\text { Paraplegia } \\
\begin{array}{l}\text { TIO on one side } \\
\text { TII on the other }\end{array}\end{array}$ & 9 & 0 & 0 \\
$\begin{array}{l}\text { TII } \\
\text { Below TII } \\
\begin{array}{l}\text { Total } \\
\hline\end{array}\end{array}$ & 4 & 2 & 50 \\
\hline
\end{tabular}

(b) In the incomplete syndromes (Table II):

The painful sensitivity is still present in the anterior injuries sparing the posterior columns.

On the contrary there is an anaesthesia of the testis in posterior syndromes of the spinal cord.

In all the Brown-Sequard syndromes, both testicles have a painful sensitivity after squeezing. In some cases we noticed a response at a lower level, as a reflex in flexion, and sometimes a squeezing of the testicle starts a phenomena of massreflex: shivers, pilomotor erection, headache.

\section{TABLE II}

Testicular sensitivity in every type of incomplete paraplegia

\begin{tabular}{|c|c|c|c|}
\hline Incomplete & No. of cases & $\begin{array}{l}\text { Testicular } \\
\text { sensibility }\end{array}$ & $\%$ \\
\hline \multicolumn{4}{|l|}{ Above Tio } \\
\hline Thermoanalgesia & II & I I & 100 \\
\hline $\begin{array}{l}\text { Posterior cordonal synd. } \\
\text { Brown-Sequard and }\end{array}$ & 2 & 0 & 0 \\
\hline anterolateral synd. & 7 & 7 & 100 \\
\hline Syringomyelia & I & I & 100 \\
\hline Tio Thermoanalgesia & 2 & 2 & IOO \\
\hline \multicolumn{4}{|l|}{ Below Ti I } \\
\hline $\begin{array}{l}\text { Anterior or posterior } \\
\text { syndromes } \\
\text { Paraplegia associated }\end{array}$ & 4 & 4 & 100 \\
\hline with polyneuritis & I & 0 & 0 \\
\hline Total & 28 & & \\
\hline
\end{tabular}


TABLE III

Testicular sensitivity and fertility

\begin{tabular}{|c|c|c|c|c|c|c|c|}
\hline & \multicolumn{3}{|c|}{ Active spermatogenesis } & \multicolumn{4}{|c|}{ Inactive or blocked spermatogenesis } \\
\hline & & & $\begin{array}{l}\text { Testicular } \\
\text { sensitivity }\end{array}$ & & & & $\begin{array}{l}\text { Testicular } \\
\text { sensitivity }\end{array}$ \\
\hline Mr. Cha & C6 & Incomplete & o & Mr. Gen & $\mathrm{C}_{7}$ & Incomplete & $\mp$ \\
\hline Mr. Gue & $\mathrm{C}_{7}$ & Incomplete & \pm & Mr. Dru & $\mathrm{C}_{7}$ & Complete & 0 \\
\hline Mr. Son & C7 & Incomplete & $\bar{o}$ & Mr. Koc & C8 & Incomplete & + \\
\hline Mr. Der & C8 & Incomplete & + & Mr. Bur & $\mathrm{T}_{5}$ & Complete & 0 \\
\hline Mr. Lab & C8 & Incomplete & + & Mr. Per & $\mathrm{T}_{5}$ & Complete & 0 \\
\hline Mr. Per & $\mathrm{C} 8$ & Incomplete & 0 & Mr. Don & T6 & Complete & 0 \\
\hline Mr. Zem & $\mathrm{T}_{5}$ & Incomplete & + & Mr. Baq & $\mathrm{T}_{7}$ & Complete & 0 \\
\hline Mr. Bor & T9 & Incomplete & + & Mr. Mic & Ti I & Complete & 0 \\
\hline Mr. Reb & TII & Complete & + & Mr. Qua & Tro & Complete & 0 \\
\hline Mr. Mur & TI2 & Complete & 0 & Mr. Pon & TI2 & Complete & + \\
\hline Mr. Pat & $\mathrm{L}_{3}$ & Complete & + & Mr. Let & $\mathrm{LI}_{\mathrm{I}}$ & Complete & + \\
\hline Mr. Fer & $\mathrm{L}_{4}$ & Complete & + & Mr. Ser & LI & Complete & + \\
\hline Mr. Vin & D6 & Complete & 0 & \multirow{2}{*}{\multicolumn{3}{|c|}{ (blocked sp) }} & ++ \\
\hline \multicolumn{4}{|c|}{ Biopsy Ist week } & & & & \\
\hline \multirow{2}{*}{\multicolumn{3}{|c|}{$\begin{array}{l}\text { Mr. Mer C8 Complete } \\
\text { Biopsy 5th year }\end{array}$}} & 0 & \multirow{2}{*}{\multicolumn{3}{|c|}{$\begin{array}{l}\text { Biopsy before } \\
\text { Ist month }\end{array}$}} & \\
\hline & & & & & & & \\
\hline
\end{tabular}

\section{Sensitivity and Fertility of the Testis}

In 27 spinal cord injured patients we compared the results of the pressure on the testis with the histological data of the testicular biopsy (Table III).

\section{Testicular Sensitivity and Type of Bladder}

The recovery of Budge's centre in $\mathrm{S}_{2}, \mathrm{~S}_{3}$ and $\mathrm{S}_{4}$, under a complete transverse injury, is the condition for a recovery of a reflex bladder.

In some spinal cord injuries, the bladder does not seem to recover a quick reflex action. During cystomanometry the detrusor doesn't show any response which is obvious at the level of the sphincter (electromyography); we sometimes see complete myelomalcia following an arterial injury (Adamkiewicz syndrome).

In the remaining cases the reflex function of the detrusor always reappears after a while: that's the reason why we wanted to compare the painful sensitivity of the testis and the eventuality of a cutaneo-abdominal reflex, with the feeling of distension of the bladder.

Above $T 8-T 9$, there is often information of the vesical distension which is revealed by a manifestation of a mass-reflex (shiver, pilomotor erection, headache, sweating). Intense testicular pressure gives the same manifestations.

Below $T_{I}$, from TI i in the complete transverse syndromes, patients feel their vesical refilling.

At TIO, the paraplegic patients in our series, with a transverse injury have no feeling at all during the vesical refilling, as they have no feelings during the squeezing of the testicles.

Besides, the two ataxic patients have no vesical nor testicular sensitivity. 


\section{Discussion}

\section{Semiological Value of the Painful Sensitivity of the Testis}

In the cord syndrome. The pressing of the testis is only painful in complete syndromes below Tio, never in Tio or above. In the transverse syndromes above T8, the pressure of the testis leads to a mass-reflex. We deduce that the spinal cord receives the sensitivity of the testis at Tio level and probably at $\mathrm{T}_{9}$ and $\mathrm{T} 8$ (and not at LI-L2) (Chapelle et al., 197I).

Dejerine (1914) stated that the painful sensitivity of the testis disappears in Tabes; we confirmed this sign in posterior spinal cord injuries. On the other hand sensitivity does exist when only the anterior part of the cord has been injured.

Lastly, in the Brown-Sequard syndromes, patients feel pain at the pressure of both testes.

Therefore we deduce: $(a)$ that the posterior tracks of the cord conveys the painful sensitivity of the testis; (b) that this sensitivity ascends directly for a part, and crosses to another part.

In every incomplete syndrome above $\operatorname{TII}_{\mathrm{I}}$, the painful sensitivity of the testis means the wholeness of the posterior tracks of the cord.

In complete syndrome above $\mathrm{T} 8$, a mass-reflex produced by pressing the testis means that the spinal shock will disappear.

Semiological value of testicular fertility. In spite of our assertions (Leriche et al., 1977/78; Perrin, 1976) as well as Tsuji's et al. (1960), the painful sensitivity of the testis after squeezing doesn't mean fertility; the tracks for the autonomous function of the cord travel along different paths and their way out is certainly not situated in Tio but much lower; we could find proof of it in the poor histological findings on biopsies of patients injured in $\mathrm{T}_{12}$ or $\mathrm{LI}_{1}$, whereas on the contrary they are good at lower levels.

On the other hand, the result of the biopsy depends on too many factors, so that any correlation cannot be defined with certainty (precocity of the biopsy, diencephalo-hypophysar activity (Auroux, 1974)).

A sweating test (Bors et al., 1950) may mean the preserving of a cutaneous vaso-motricity; and even so that doesn't always prove a correspondence between a cutaneous level and the vaso-motricity of the testis.

The semiological value of the painful sensitivity of the testis in the functioning of neurological bladders. The ureteral innervation is presumed to correspond to the level Tro (H. Head), which would coincide with the testicular irradiation of ureteral pain as well as with pain projected into the ureteral area during the squeezing of the testicles.

Therefore, the persisting painful sensitivity of the testis is a favourable sign for a persisting ureteral innervation.

As for the functioning of the bladder itself, it cannot be forecast only through the sensitivity of the testis.

In some injuries with no recovery of the sacral reflex, the absence of any sensitivity of the testis doesn't mean anything of a lesional localisation, more especially as the research for the inferior cutaneo-abdominal reflex already brings us interesting information about the reflexibility of TIO-TI2 segments that concerns a part of the vesical contraction. 
The interesting information brought about by the painful sensitivity of the testis by squeezing, is the vesical sensitivity during filling up and the feeling of a need for micturition.

Above T8, the phenomena of autonomic dysreflexia, when squeezing the testis, lets us foresee a possible information about the bladder.

From TII and below, the sensitivity of filling the bladder also exists, like the one of the testis during squeezing. We can compare this fact with the trigonal sensitivity of the paraplegic during cystoscopy: the sensitivity of the trigonal area might go along the same paths as those of the testicles. That is in fact the most interesting point, since we can foresee, with a simple squeezing of the testicles, if patients with complete paraplegia will or will not be able to feel their bladder filling, except between T8-Tı injuries (Table IV).

\section{TABLE IV}

Correlations between the testis and bladder sensitivity

\begin{tabular}{|c|c|c|c|c|c|c|c|}
\hline & & & $\frac{\text { Cut ab }}{\text { sup. }}$ & $\begin{array}{l}\text { eflex. } \\
\text { inf. }\end{array}$ & $\begin{array}{l}\text { Sensit. } \\
\text { testis }\end{array}$ & $\begin{array}{l}\text { Bladder } \\
\text { reflex }\end{array}$ & $\begin{array}{l}\text { Bladder } \\
\text { feeling }\end{array}$ \\
\hline Mr. Fer & $\begin{array}{l}\text { Incomplete } \\
\text { (Ataxia) }\end{array}$ & $\mathrm{C} 8$ & + & + & 0 & $\simeq 20 \mathrm{~cm}$ & 0 \\
\hline Mr. Gui & Complete & $\mathrm{T} 8$ & 0 & + & 0 & $15 \mathrm{~cm}$ & 0 \\
\hline Mr. Com & Complete & $\mathrm{T} 8$ & + & 0 & 0 & 0 & 0 \\
\hline Mr. Gar & Complete & Tro & + & 0 & 0 & 0 & 0 \\
\hline Mr. Cam & Complete & Tio & + & 0 & 0 & $\operatorname{Max}$ & 0 \\
\hline Mr. Gra & Complete & Tio & + & 0 & 0 & 0 & 0 \\
\hline Mr. Bar & Complete & Tio & 0 & 0 & 0 & 0 & 0 \\
\hline Mr. Hao & Complete & Tio & + & 0 & 0 & $100 \mathrm{~cm}$ & 0 \\
\hline Mr. Sco & Complete & Tio & + & 0 & 0 & $50 \mathrm{~cm}$ & 0 \\
\hline Mr. Qua & Complete & Tio & + & 0 & 0 & Max & 0 \\
\hline Mr. Gir & Complete & TII & + & 0 & + & $\simeq 5 \mathrm{~cm}$ & + \\
\hline Mr. Mar & Complete & TII & + & 0 & + & $40 \mathrm{~cm}$ & + \\
\hline Mr. Nem & Complete & TII & + & + & + & $\simeq 20$ & \pm \\
\hline Mr. Mur & Complete & TII & + & 0 & + & 50 & + \\
\hline Mr. Fan & Complete & TI2 & + & + & + & 50 & \pm \\
\hline Mr. Ber & Complete & TI2 & + & + & + & 50 & + \\
\hline Mr. Reb & Complete & TI2 & + & + & + & $20 \mathrm{~cm}$ & + \\
\hline Mr. Rey & Complete & $\mathrm{LI}_{\mathrm{I}}$ & + & + & + & $\operatorname{Max}$ & + \\
\hline Mr. Bat & Complete & LI & + & + & + & $100 \mathrm{~cm}$ & + \\
\hline Mr. Mic & Complete & TII & + & 0 & + & $50 \mathrm{~cm}$ & \pm \\
\hline Mr. Bor & Incomplete & Tio & + & + & & & + \\
\hline
\end{tabular}

\section{Conclusion}

We found it interesting to report our experience about a sign which is rarely mentioned: the painful sensitivity of the testis during squeezing in paraplegic patients, and we have found that this sign could be very useful for the eventual starting of any rehabilitation of the bladder.

It brings us semiological information about the level, and also about the topography of incomplete syndromes, but not about fertility. 


\section{RÉSUMÉ}

Les auteurs apportent leur expérience de la sensibilité douloureuse du testicule à la pression chez l'homme paraplégique à propos de 85 cas. Cette information comporte une valeur semiologique sur le niveau et la topographie des syndrômes médullaires.

Complets et incomplets. On ne peut en tirer aucun argument pour la fertilité testiculaire. La rééducation des vessies neurologiques peut, à l'inverse, tenir compte, pour le type de miction, de la présence ou de l'absence de cette sensibilité.

\section{ZUSAMMENFASSUNG}

Die Autoren bringen Ihre Erfahrung über schmerzhaftes Empfindungsvermögen bei Pressen des Hoden, bei 85 Männern mit Querschnittslähmung.

Diese Information enthält einen Wert für das Niveau und die Topographie der vollständigen und unvollständigen Syndrome. Man kann kein einwandfreies Argument für die Fruchtbarkeit des Hodens geben.

Aber die Verkleinerung der neurologische Harnblase muss berücksichtigt werden für die Funktion des Urinierens bei Anwesenheit oder Abwesenheit dieses Empfindungsvermögen.

\section{REFERENCES}

Auroux, M. (1974). La spermatogénèse, le système nerveux central et le paraplégique. fournal d'Urologie et de Néphrologie, 80, 62 I, 630.

Bors, E., ENGLe, E. T., RosenQuist, R. C. \& Holliger, V. H. (I950). Fertility in paraplegic males. F. Clin. Endocrinol., ro, 38I-398.

Chapelle, P. A., Piera, J. B., Pannier, S., Lacert, P. H. \& Grossiord, A. (I97I). Fonctions sexuelles et génitales chez les paraplégiques. Rev. Prat., 21, 3785-3794.

Dejerine, J. (I9I4). Seméiolgie des affections du système nerveux. Masson Edit.

Leriche, A., Berard, E., Vauzelle, J. L., Minaire, P., Girard, R., ARChimbaud, J. P. \& BourRET, J. (I977/78). Histological and hormonal testicular changes in spinal cord patients. Paraplegia, I5, 274-279.

Perrin, B. (1976). Le testicule dans les paraplégies médullaires. M.D. Thesis, Lyon.

Tsuji, I., KnAKajima \& MoRimoto (I960). The sexual function in patients with spinal cord injury. F. Nerv. Ment. Dis., I31, I2 I-I23.

\section{Announcement}

The Third Congress of the International Rehabilitation Medicine Association will take place from the 2nd to 7 th July 1978 in Basle, Switzerland. Applications to be sent to the President's Secretariat: Medical Department, $\mathrm{CH}-73$ Io Bad Ragaz. Telephone 0859 1906. This Congress will be of interest to many members of the Society. 